with Mr. Wilkinson in this particular (Q.J.G.S., vol. lxxii, pp. 152-5, and pl. xii).

In East Islay, for $8 \frac{1}{2}$ miles out of a possible 13, Mr. Wilkinson has mapped a band of slates separating the conglomeratic beds mentioned above from the main quartzite lying north-west of them. I have little doubt that fuller exposures would show this band of slates to be really continuous in Islay. At any rate, following in Mr. Wilkinson's footsteps, I have found it everywhere in a similar position in Jura, where its above-sea outcrop totals another 20 miles measured along the strike. The slates of this band I have called the Jura Slates. I agree with Mr. Wilkinson that appearances on the south coast of Islay strongly suggest that the conglomeratic group lying south-east of the Jura Slates has derived material through erosion of the latter. But I disagree with him when he declares that the Jura Slates are exposed along the crest of an anticlinal fold, and that the conglomeratic quartzite south-east of them is merely an outlier of the main quartzite farther north-west. My reasons are as follows:-

(1) There is no field-appearance suggesting the postulated fold.

(2) The Jura Slates along almost all their outerop are assymetrical, with a grey division against the main quartzite and a black division against the conglomeratic group. (I can speak with certainty in regard to this feature in the southernmost exposure in Islay, and in all except one occurrence in Jura. At the extreme north of Jura, the group is wholly black. Unfortunately, I have no detailed notes regarding exposures in Islay, except the southern one figured op. cit., p. 154.)

(3) The conglomeratic group is everywhere distinguishable on the ground of texture, from the main quartzite occurring on the other side of the Jura Slate outcrop.

It will be seen, therefore, that the evidence which points to the conglomeratic group being later than the Jura Slates, places them at the original top, rather than the original base, of the Islay Quartzite taken as a whole.

Edinburgh.

E. B. Bailey.

\title{
PETROGRAPHIC NOMENCLATURE.
}

SrR,-I am led to stir up these muddy waters once more by reading Mr. Dixey's interesting account of the norite of Sierra Leone (Q.J.G.S., 1922, pt. 4). Some years ago (1918) I gave a brief account of this norite in the Geological Magazine (and, by the way, I wish Mr. Dixey had not said that I " translated Gürich's work", for the few observations that I described were my own), and I mentioned three facies, namely a pegmatitic norite, a medium-grained norite, and an aplitic norite or micronorite. Mr. Dixey recognizes the same three facies, but the rock that I called micronorite he calls beerbachite, and he gives the name norite-aplite to another rock which consists chiefly (sometimes almost wholly) of quartz, orthoclase, and acid plagioclase, with 
small quantities of pyroxene, etc. He tells us that this rock is related to the dolerite dykes which cut the norite, "as much as, or even more than, to the norite."

Now, the substitution of beerbachite for micronorite is warrantable, though personally I am opposed to the practice of giving different specific names to rocks which, like norite and beerbachite, differ only in texture. But in the application of the name " noriteaplite" my views and those of Mr. Dixey are totally at variance. To me an aplitic norite, micronorite, or norite-aplite is a rock of noritic composition and aplitic texture ; to Mr. Dixey a noriteaplite seems to be a rock of aplitic texture derived from a noritic magma, even though it should consist, as he says, " almost wholly of quartz and micropegmatite."

With no idea of criticizing Mr. Dixey, I just wish to ask how petrology can ever progress when it is possible for such utterly different meanings to be attached to the same name? I know that it is hopeless to expect all petrographers to adopt one system of classification, but surely it is time that we came to an agreement on a few elementary points about the construction and application of rock names?

Will not the Geological Society's Committee on Petrographic Nomenclature, which has already rendered a conspicuous service by killing off many obsolescent names, give us a further lead by laying down a few conventions to regulate:-

(1) The method of construction of compound names.

(2) The minimum requirements for the acceptation of proposed new specific names? (Adding, if possible, lists of those that do and those that do not fulfil the requirements.)

Because Petrographers cannot agree on all points, there is no reason why they should not try to agree on as many as possible, and the example that I have given above shows how desperate the need of some agreement is.

UNIVERSTTY, STELLENBOSCH,

S. J. Shand.

SoUTh AFrica.

16th April, 1923. 